\title{
LIFELONG EDUCATION AS A KEY FACTOR OF THE TRANSFORMATION AND DEVELOPMENT OF THE HUMAN CAPITAL'S POTENTIAL
}

\author{
Anna Tatarinceva \\ The Baltic International Academy, Latvia \\ Ina Gode \\ The Latvian Agricultural University, Latvia
}

\begin{abstract}
The Actuality of the proposed research is caused by the facts that the rapid development of market relations in the Latvian economy and a high level of life in the "old countries" of the European Union affect the outlook of the majority of young people in Latvia. There is a tendency to reduce the motivation for obtaining fundamental education by giving preference to acquisition of certain professional skills allowed to get 'quick money". The Object of the research is the transformation process of students' beliefs, values, competences, experience during their lifelong learning. The Aim of the research in to analyze the influence of lifelong education on the transformation of students' beliefs, values, competences and experience. The Methods of the research are the following: 1. theoretical methods: the theoretical analysis of the scientific literature on the given problem; 2. quantitative methods: questionnaires; 3. The empirical analysis of the survey's answers given by students of Latvian higher and vocational schools about the transformation of their beliefs, values, competences, experience during the process of lifelong learning. The Baltic International Academy (Riga, Latvia), The Latvian Agricultural University and the Jelgava College (Jelgava, Latvia) were used as the experimental Base of the research.
\end{abstract}

Keywords: adult, beliefs, capital, competence, development, experience, lifelong education meaning, purposes, perspectives, potential, schemes, student, transformation, values.

\section{Introduction}

"Humans should understand the meaning of their experience, learn to make their own interpretations rather than act on purposes, beliefs, judgements and feelings of others. Facilitating such understanding is the cardinal goal of adult education" Jack Mezirow (1997)

It is extremely important to understand the indivisible unity of a physical, spiritual and intellectual components of the notion "human potential" which is the base of the economic growth, prosperity and health of any nation nowadays. The significance of intellectual, spiritual and cultural constituents of individual's potential contribution is increased and changed as it forms and develops social 
capital of any state dependent directly on individual's abilities to perceive, process and implement obtained new knowledge, skills and competences in order to adapt to changes and develop her/his own potential more. Human resources are the most important components of any state's potential. Considerable attention in contemporary scientific literature is paid to the analysis of the concept "human capital" in opposition to and sometimes identification with the notion "human potential". Human potential represents the developed innate abilities of human beings influenced the results of activities in which they are involved (Adler \& Kwon, 2012). The essence of the notion "human capital' is determined as a set of human professional knowledge, skills and competences that can generate revenue. Education, vocational training and health care are considered to be the main types of investment in human beings (Bourdie, 2006; Coleman, 2010).

The Indian scientist Sen (1999) in his famous "capability approach" believes that the process of human potential development is not only the process of physical and economic well-being but mainly it implies greater freedom of choice, each individual could choose the certain purpose and way of life which he/she considers preferable from a large number of options. Income is only one choice desirable for a man but it does not determine all the opportunities and diversity of human life. The economic growth, according to Sen (1999), can contribute to human development when it provides an adequate level of public expenditure which are invested in the social environment in the equitable distribution of economic resources, and the government provides equal opportunities in spheres of education, health care, security, political and civil rights.

The population of the Latvian state is decreased because of the population growth's negative indices (they were equal to - 425 in the 2014) and migration (more than 250000 people left Latvia during last years) (Melihovs, 2015). The Latvian population is aging. The proportion of seniors increases; it was equal to $18 \%$ in 1990, $28 \%$ in the 2013 and, according to forecasts, it is going to be equal to $36 \%$ in the 2030 (Melihovs, 2015).

But it is possible to increase human potential as a factor of the economic growth by raising the level of education and vocational training of population. The government should increase financial flows directed to lifelong education. Expenditures on education are considered as the investment in human capital, modern educational technologies. This investment should be paid off no later than obsolescence of knowledge (Болтнева \& Филаткин, 2014). The rapid development of market relations in Latvian economy and a higher level of life in the "old countries" of the European Union influence the outlook of the majority of young people. There is a tendency of a decline in motivation for obtaining fundamental education, that is why the problem of searching for additional 
internal sources of economic growth exists. One of such sources is the system of lifelong education. Lifelong learning, Mezirow (1978) calls it transformative learning, involves changes of learners' behaviour, understanding their own experience and the surrounding world, perceptions, and values. Mezirow (1997) in his Theory of Transformative Learning claims that the most significant adult learning makes an individual to be aware of the ways in which unquestioned assumptions acted as taken-for-granted beliefs. This type of learning constrains and sometimes distorts the ways by which people make their sense of the world. These assumptions have two dimensions:

1. habits of expectations (so called 'meaning perspectives'), which could be considered as "filters" for shaping people's meaning making; and

2. individual's beliefs, values, judgements, attitudes, points of view (so called 'meaning schemes') Mezirow (1997).

The survey's results of higher and professional schools' students of Latvia about the transformation of their beliefs, values, potential, understanding and implementing their learning experience are analyzed in the proposed research.

Latvia should increase human potential as the essential factor of the economic growth. The level of knowledge and professional training of each individual forms the quality and the level of human potential. In accordance with statistics, human potential development index in Latvia is included in the group determined as "very high", and takes the $46^{\text {th }}$ place in the ranking of countries (Melihovs, 2015). Nevertheless Latvia lags behind other Baltic states, for example, Estonia takes the $30^{\text {th }}$ place, Lithuania takes the $36^{\text {th }}$ place. Investments in education have an impact on the individual's social status and his/her Self-esteem increase, as well as the reproduction of spiritual and intellectual potential of society, which demands new approaches to learning and teaching. Lecturers and students meet problems, challenges and uncertainties in the domestic and external environment. Let's analyze the concept of Transformative Learning by Jack Mezirow $(1978,1991)$ where he defines the essence of learning as the process of not only assimilation of knowledge and skills but also as the process transformed the word view, values, beliefs, competences of learners.

\section{The Essence of Transformative Learning Theory (Mezirow, 1978)}

The Theory of Transformative Learning by Jack Mezirow (1978) deepens our understanding what it means to learn. It is a complicated description how learners interpret, justify, and restart the value of their experience. The transformation of meaningful schemes occur through their learning. Scientists Taylor (1998), Scott (1997) and Cranton (2004) support the opinion of Mezirow (1991) that such a transformation occurs through several stages started with the 
reorientation of dilemma. These stages include: 1.the Self-analysis; 2. the critical evaluation of an assumption; 3 . the recognition that a similar transformation occurs with other people; 4 . the investigation of new actions or roles; 5. the action plan elaboration; 6 . the knowledge and skills assimilation for this plan implementation; 7. The verification of the plan; 8. the development of competence; 9. faith in Self in new roles; 10. new integration into life on the base of a new perspective.

Mezirow (1978) in his Theory of Transformative Learning considers that the process of perspective transformation has three dimensions: 1.psychological (changes in understanding of Self); 2. Convictional (the revision of the belief system); 3. Behavioural (changes in lifestyles). The authors of the proposed research share the opinion of Mezirow (1991) who believes that Transformative Learning is the expansion of consciousness through the transformation of basic world view and specific capacities of Self. Learners engaged in critical reflection on their own experiences, change their meaning schemes - specific beliefs, attitudes and emotional reactions, thus, changing their perspectives.

Roberts \& Burge (2008) define 5 characteristics of learners existed in any learning environment: 1 . a motivational call to action; 2 . developmental stages (thinking and group processes); 3 . gender differences; 4. differences in culture; 5. learning styles. Motivation influences the amount of time which students are ready to devote to their learning, develop their competences and solve problems. Students' persistence in overcoming difficulties depends greatly on how much time students focus on learning. Students who focus on learning, are opened to new challenges (Dweck, 2012). Social possibilities also influence on motivation. Learners of all ages are motivated more when they see the usefulness of what they learn and they know how to use obtained knowledge, skills, competences in order to do something which can influence other people (Pintrich \& Schunk, 1996; McCombs, 1996). The important condition of human existence is the necessity to learn how to make their interpretations of own experience. The authors support the point of view of Mezirow (1997) that facilitating such understandings is the cardinal goal of adult education.

The key idea of Mezirow $(1978,1991,1997)$ is that learning occurs as soon as there is a paradigm shift, some changes of prospects or when an adult rebuilds own values, beliefs and the world views. The main focus should be on the learner's experience and ways by which he/she analyzes it. Mezirow (1978) determines several ways to promote individuals' critical thinking and awareness. It is very important how a person interprets his/her experience, what meaning is attached to it, how it could be changed in order to get new understanding of what happened and what could be learnt from that for future activities. People should learn to change their schemes - values, specific beliefs, attitudes, and emotional reactions - that in turn leads to the transformation of perspectives. The 
authors support the point of view of Mezirow (1991) that the transformation of perspectives is the process of understanding how and why people's assumptions limit the way of their perception, understanding and feeling of the world, the process of changing structures of habitual expectations. People should comprehend that in order to create a possible perspective more perfect, and finally make a choice based on new understanding. The transformation of perspectives explain how meaningful structures which have been mastered over a lifetime become transformed. This type of learning has its roots in the process of creating a sense which is a base of constructivism, where the environment should provide support, promote a dialogue, critical understanding of the studied material and Self (Piaget, 1967).

The problem of Transformative Learning is urgent in Latvia nowadays because the analysis of the current situation of our state shows that each individual should be aware of the need to obtain new knowledge and skills, to be in the centre of contemporary lifelong educational process in order to survive and achieve a higher level of life and its quality. Thus, lifelong learning, knowledge and skills' transfer are very important because "transformative learning promotes autonomous thinking" (Mezirow, 1997). Thus, he supports the idea of Carl Jung (1921) who is the first scientist discovered that transformative learning allows a learner to form his/her personality, differ from others, develop own personality, to be an individuality.

\section{Conditions for Successful Transformative Learning}

Learners should share the responsibility with their lecturers for creating conditions for successful Transformative Learning. The main result of Transformative Learning is the further development of students' competences, abilities to focus on a new idea, position, or achieve a shift in a new paradigm, thus taking a new view on the same idea. Singley \& Anderson (1989) consider that specific facts and skills should coincide in the initial and subsequent learning, and the degree of knowledge transfer successfulness depends on the level of initial learning, it should be adequate. Students should control continuously his/her progress in own learning and implement an effective feedback with their lecturers that is one of the most important preconditions for successful learning (Torndike, 1932).

\section{The Empirical Analysis of the Survey's Results Conducted at Vocational and Higher Schools of Latvia}

The authors of the proposed research conducted a survey of students of The Jelgava College, The Latvian Agricultural University and The Baltic 
International Academy who were given questionnaires during SeptemberDecember 2015.

Students were asked to answer such a question, if learning transforms their beliefs, values, attitudes, understanding their experience and perspectives as the American scientist Jack Mezirow $(1978,1991,1997)$ believes in his Theory of Transformative Learning. Respondents had to circle the most appropriate answer among "No" / "It is difficult to answer" / "Yes", and give a short example confirmed their opinion.

210 respondents took part in this survey, they were 111 female students and 99 male students aged between 17-33 years.

The results of this survey were the following:

177 students - (it is equal to $84 \%$ of all respondents) - gave the positive answer "Yes"; " 22 " respondents (it is equal to $11 \%$ of all respondents) gave the negative answer "No"; and 11 respondents (it is equal to $5 \%$ of all respondents) circled the answer "It is difficult to answer".

\section{Respondents' answers}

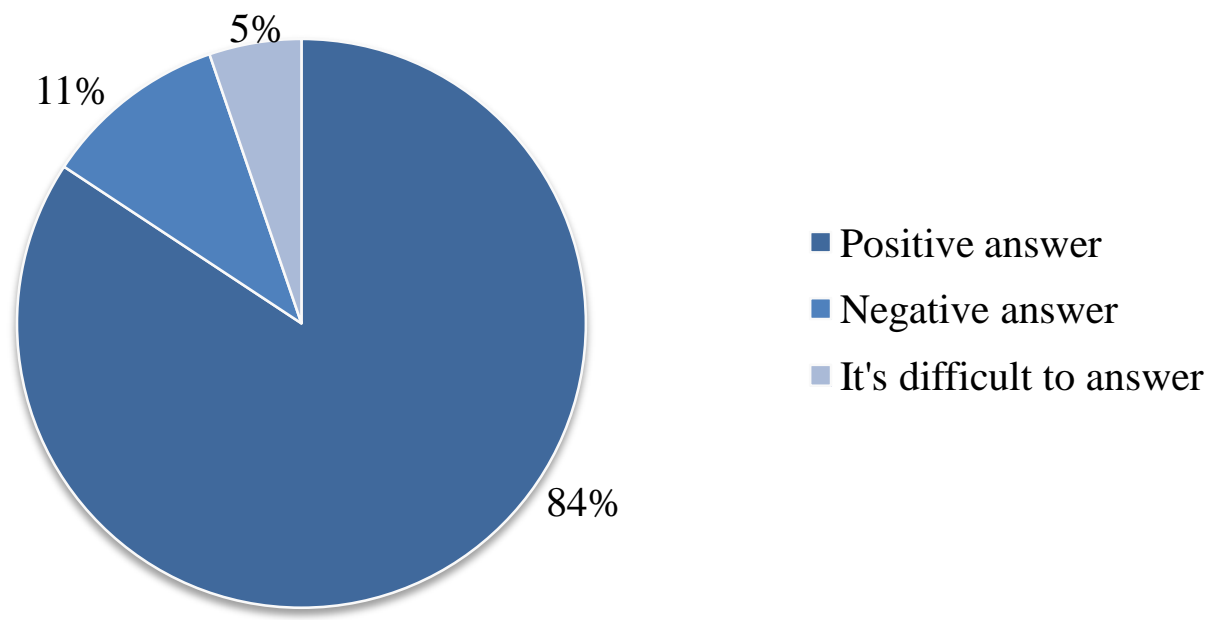

Figure 1 The results of the survey

Students who answered "Yes" wrote: " ... learning makes a person wiser, it broadens the mind, expands an outlook, he/she looks at many things and problems differently than before...", “... I wanted to buy a car, but after watching a film about the Greenhouse effect and the depletion of the ozone layer at the lecture, I thought if I really needed a car with a powerful engine", “ ... the more you know, for example, about how your parents raised and brought you up, the more you start to think about many things differently, your beliefs are changed...", “ ... new information obtained during learning changes our beliefs and values significantly...", “... learning broadens our horizon, allows critically reflect on experience, it changes many beliefs and values...", “... learning is the 
greatest value of an individual which allows him/her to change him/herself, own values and beliefs...", “ ... a person can assess his/her values, ways of thinking and beliefs only by studying, comparing and being aware of different processes...", “ ... when we collide with other values in the process of education, understand what happens around us, our understanding about our values and actions changes...", "... people become cleverer and their values, beliefs are changed", “... I learn at the veterinary faculty, I started to look at my values, beliefs and animals quite differently than before by studying the anatomy of animals. It changed my way of thinking and perception of life...", " ... when a person learns he/she discovers a lot of new and that may change his/her values to 180 degrees...", " ... my values changed very much after studying at school and university..."," ".. all your values are changed greatly after studying because your experience, susceptibility, the level of development and understanding are also changed, the causal relationships and analytical abilities are formed...", " ... learning gives us wider possibilities to implement new knowledge and it changes our personality, beliefs and values...", " ... you are clever and you want to be cleverer, that gives you the opportunity to find a wellpaid and interesting job and implement a higher level of life...", “... values are changed with the development of personality, the study of logic, knowledge of the world and with age, because a person becomes wiser and his/her perception of life is also changed...", " ... while learning you become able to make more reasonable decisions and change own values...", " ... learning and reading change values and horizon of a person greatly, help to achieve a lot in life...", "“ ... a person changes his/her world view and values by learning very much. For example, 50 years ago our history text-books gave people completely different information than now...", " ... education determines higher standards in life, confidence in Self and future...", “... I conducted the research about a scientist Stephen Hawking, read some his books about the universe, that influenced on my values and outlook on life greatly...", “ ... new knowledge change our outlook on many things, our values change also with age. For example, when I was 20 , I liked to go to the disco but I enjoy visiting the opera now".

Respondents answered "No" motivated their choice by the following phrases:" values and beliefs are laid by parents, family, friends in childhood and it is difficult to change them". Respondents who circled "It is difficult to answer" wrote that the change of values and beliefs depended on many reasons experience, a future profession, a family, a person, a lifestyle...

\section{Conclusion}

The development of market relations in the post-Soviet space leaves its mark on the formation of world outlook, reassess spiritual and social values. It 
seems that on one hand young people lost interest in fundamental education by giving preference to acquisition of certain professional skills allowed to get "quick money". On the other hand there is dissatisfaction with the learning and teaching processes based on the combination of accessibility to many information sources with simply cumulative methods of obtaining knowledge and skills which rapidly become obsolete under modern conditions of the development of science and industry. Latvia faces a complicated demographic situation and way out of that is the development of human capital potential improvement as the key factor of the economic growth. The Indicator of the Human Development Index in Latvia is the lowest in the Baltic States that could be explained by inadequate funding of education and science.

It is necessary to increase the interest of students to lifelong learning as it is the constant process of knowledge, skills, competences updating throughout life, to create new educational technologies, combine theoretical knowledge obtained at professional and higher schools with practice. The Latvian Ministry of Education and Science should plan the enrollment of students for certain specialties more adequately in line with demand of the Labour Market. The government of Latvia should invest much more money for the establishment and development of industrial and scientific enterprises, working places where our young people could implement their obtained knowledge, skills, competences, get interesting and well-paid job and achieve a high level of life.

"Obtaining qualitative education is the key condition for success in future life, it is the main value of personality, learning really transforms values and beliefs of individuals in the positive direction, promote the development of critical and analytical thinking, personal enrichment and the achievement of higher standards and quality of life"-such approvals express the main ideas of the majority of respondents' answers received in our survey.

The authors of the research conclude that contrary to the claims that the prestige of professional and higher education falls the majority of students associate obtaining good education with the essential development of personality and the improvement of life quality.

The results of the conducted survey confirm that lifelong education is a key factor of the transformation and development of human capital's potential.

\section{References}

Adler, P. S., \& Kwon, S. (2012). Social Capital: Prospects for a New Concept. Academy of Management Review 27 (1), 17-40.

Bourdieu, P. (2006). The Form of Capital. NY: Aldine de Gruyter.

Burge, E., \& Roberts, J. M. (2008). Technology and Adult Learning. CA: McCraw.

Coleman, J. (2010). Social Capital in the Creation of Human Capital. Cambridge: Cambridge University Press. 
Cranton, P. (2004). Self-Directed and Transformative Instructional Development. Journal of Higher Education, 65, 726-744.

Dweck, C. (2012). How You Can Fulfil Your Potential. Cambridge: Cambridge University Press.

Jung, C. (1921). Psychological Types. NY: Harcourt Brace.

McCombs, K. (1996). Building Consensus. NY: TX.

Melihovs, A. (2015). Baltijas Valstu un Eiropas Ekonomiskās Aktivitātes Kopīgie Faktori. (Common Factors of Economic Activities in the Baltic States and Europe) Rīga: Jumi.

Mezirow, J. (1978). Perspective Transformation. Adult Education, 100-120.

Mezirow, J. (1991). Transformative Dimensions of Adult Learning. San Francisco, CA: Jossey - Bass.

Mezirow, J. (1997). Transformative Learning Theory to Practice. New Directions for Adult and Continuing Education, 74, 5-27.

Piaget, J. (1967). The Psychology of Intelligence. NY: Routledge.

Pintrick, R., \& Schunk, D. (1996). Motivation in Education. NY: Merrill Prentice Hall

Scott, S. (1997). The Grieving Soul in the Transformative Process. CA: Jossey-Bass.

Sen, A. (1999). Development as Freedom. Oxford: Oxford University Press.

Singley, M., \& Anderson, J. R. (1989). Learning and Transfer of Cognitive Skills. Cambridge: Harvard Press.

Taylor, E. (1998). The Theory and Practice of Transformative Learning. NY: Sunny Press.

Thorndike, E. (1932). The Fundamentals of Learning. NY: Paul Chapman.

Болтнева, Н. Ю., \& Филаткин, В. Н. (2014). Образование и Экономический Рост. (Education and The Economic Growth). Москва: Экономика. 